\title{
Et temanummer som undersøker hva det innebarer å forske med kunsten
}

\author{
Tone Pernille Østern og Mari Ann Letnes* \\ NTNU Norges teknisk-naturvitenskapelige universitet
}

Å forske med kunsten innebærer å forske i, gjennom og tilknyttet kunstneriske prosesser, kunstprodukter og kunstpedagogiske praksiser. Dermed kan og bør disse gjøres til gjenstand for metodologisk drøfting, noe som er hensikten med dette temanummeret. I del 1 av temanummeret, som publiseres i desember 2017, bidrar åtte forfattere med like mange artikler. I del 2 av temanummeret, som kommer i mars 2018, bidrar omtrent like mange. I temanummerets artikler beskriver, problematiserer og diskuterer kunstner-forskere, kunstpedagog-forskere eller forskerstudenter, hvordan de utvikler metodologier og metoder når de forsker med kunsten, samt hvilke verdier og utfordringer dette gir. Et temanummer med metodologisk fokus er relevant fordi det har vist seg å være utfordrende for kunstner/kunstpedagog-forskere å:

1. Avgrense et relevant problemområde for forskning

2. Artikulere forskningsspørsmål som blir formulert enten før eller gjennom forskningsprosessen

3. Utvikle relevante metoder for å produsere og analysere kunstneriske/kunstpedagogiske forskningsmaterialer

4. Være metodologisk transparente og argumentere for viktigheten av sin forskning

(se også Academy of Finland, 2009, s. 23)

I temanummeret gir artikkelforfatterne eksempler på, problematiserer og diskuterer disse utfordringene.

I temanummeret bruker vi begrepet å forske med kunsten som et samlebegrep for det som både på engelsk og i nordiske språk har mange navn og varianter. Begreper som brukes og debatteres, og som samlebegrepet omfatter, er blandt annet arts-based research, arts-led research, practice-led research, art as research, artistic research, ARTography, performative research og tilsvarende nordiske begreper som kunstbasert, kunstledet, praksisledet, performativ og kunstnerisk forskning. Også begrepet post-qualitative research

^Korrespondanse: Tone Pernille Østern, Institutt for lærerutdanning, NTNU, 7491 Trondheim. Epost: tone.pernille.ostern@ntnu.no

(C)2017 T.P. Østern og M.A. Letnes. This is an Open Access article distributed under the terms of the Creative Commons Attribution 4.0 International License (http://creativecommons.org/licenses/by/4.0/), allowing third parties to copy and redistribute the material in any medium or format and to remix, transform, and build upon the material for any purpose, even commercially, provided the original work is properly cited and states its license. 
brukes. I Norge brukes begrepet kunstnerisk utviklingsarbeid, som er sidestilt med forskning i universitets- og høyskoleloven fra 1995.

For filosofen Gilles Deleuze er ikke begreper beskrivelser som brukes for å benevne en verden som allerede finnes på en ferdig eller statisk måte, men er heller å forstå som en positiv kraft. Begrepsskaping er noe som er med på å skape og forvandle det liv vi forsøker å sette ord på samtidig som det utfolder seg (Colebrook, 2010, s. xvii). Slik ser også vi på begrepet eller sammenstillingen å forske med kunsten, samt de ulike benevnelser som vi samler under det. Å begrepsliggjøre på feltet handler om å gripe og begripe, skape og formidle et høyinteressant, eksplorerende, uferdig og ekspansivt forskningsfelt. Vi mener at det å forske med kunsten har sin selvsagte plass på et bredt forskningsfelt, på samme måte som kunsten i seg selv er en selvsagt, nødvendig og verdifull del av et hvert samfunn og på alle utdanningsnivåer. Kunst med sine mangfoldige uttrykksformer er en måte å vite, oppleve, forstå, bearbeide og kommunisere verden på, men hvordan man forsker på dette relativt unge forskningsfeltet diskuteres kontinuerlig. Vi tok initiativ til temanummeret fordi vi ønsker å slippe til ulike forfattere som kan bidra til diskusjonene, holde dem varme, konstruktivt provosere dem, forme dem og stabilisere dem.

På mange måter vil vi plassere det å forske med kunsten inn under det som karakteriseres som post-kvalitativ forskning. Med dette ønsker vi å signalisere at vi ikke lenger lar skriftlige uttrykksformer dominere, samtidig som vi heller ikke unngår det skriftlige. Det skriftlige preger kvalitativ forskning - det meste blir før eller siden omsatt i skriftlig tekst, noe vi også oppfatter som verdifullt og viktig for artikulasjon på feltet. Men, noe blir alltid «lost in translation», ikke minst mellom ulike formspråk, eller fra en kunstform til verbalspråk (jfr. Hannula, Suoranta \& Vadén, 2014 ) - samtidig som noe nytt vinnes. I post-kvalitativ forskning anerkjennes tanken om at forskning kan skje også $i$ andre uttrykksformer som musikk, bildekunst, dans og teater. Dette er sammenfallende med en av definisjonene for artistic research, at forskningsspørsmålene besvares $i$ kunstnerisk praksis. Et annet trekk ved det post-kvalitative, er at forskerens oppmerksomhet rettes mot ulikheter mer enn til likheter i forskningsmaterialer. Det betyr at hovedmålet med analysen ikke nødvendigvis er å skape mønster, kategorier eller sentrale temaer, som tenderer å prege kvalitativ forskning. Isteden gjør forskeren for eksempel diffraktive eller rhizomatiske analyser. I en diffraktiv analyse søker forskeren å få fram ulikheter og potensialer (jfr. Barad, 2007; Lenz Taguchi, 2012). En rhizomatisk analyse fremstiller ulikheter og muligheter som flettverk og nettverk av tentative svar - svar uten en klar begynnelse og slutt (jfr. Deleauze \& Guattari, 1987/2013). Når man forsker med kunsten kan bricollager, assemblager og montager forstås som mulig post-kvalitativ forskning (jfr. Denzin \& Lincoln, 2005; Kara, 2015; Sharma, 2002; Torres de Eça, 2015; Kaihovirta, 2009). Samtidig som vi forsøker å ringe inn hva post-kvalitativ forskning eventuelt kan være, er det viktig å påpeke at kvalitativ forskning i seg er et forskningsfelt som har opplevd formidabel utvikling, vekst og eksperimentering, og som tøyer grensene og blander seg sammen med det som kan kalles post-kvalitativ forskning. Så isteden for å konkludere med at det har skjedd et totalt brudd mellom 
kvalitativ og post-kvalitativ forskning, vil vi si at det faktum at begrepet postkvalitativ har dukket opp, peker på et slikt begynnende brudd. Å forske med kunsten plasserer vi et eller annet sted i et spekter mellom kvalitativ og post-kvalitativ forskning. Framvoksten av det å forske med kunsten har i seg selv vært produktivt i å få fram et slikt forskningsmetodologisk spekter.

Forskere trenger å klargjøre ulike nivåer av sine valg knyttet til forskningsdesign: epistemologisk, vitenskapsteoretisk eller -filosofisk, metodologisk og metodisk. Temanummeret har metodologisk fokus, men også de andre nivåene flettes inn i det metodologiske. Vi beskriver derfor de ulike nivåene kort.

Epistemologi handler om kunnskapssyn: Hvordan vet vi det vi vet og hvordan kan vi få kunnskap om verden, og denne kunnskapens gyldighet. Epistemologi, kunnskapssyn, viser seg i valgt vitenskapsteoretisk eller -filosofisk perspektiv. Det handler enkelt sagt om hvilket (vitenskapsfilosofisk) sted du stiller deg på for å se på og fortolke ditt materiale, litt som å se på et rom fra ulike plasseringer i rommet. Nye perspektiver framtrer i det du bytter plass. Den vitenskapsfilosofiske posisjoneringen veileder forskeren $\mathrm{i}$ hans/hennes valg, og danner kontekst og logikk for forskningsprosessen.

Med metodologi mener vi den kreative, komplekse, krevende og kritiske prosess som innbefatter alle de de valg forskeren står ovenfor. Slik vi bruker begrepet, rommer det både forskerens tenkning, sansning, opplevelser, praktisk-kunstneriske arbeid og tekstarbeid, alle valg og all håndtering av etiske dilemmaer knyttet til prosessen. Metodologi forstår vi dermed som en prosess, selv om metodologi kan framstå som et produkt i etterkant, når prosjektet er beskrevet og avsluttet (jf. Østern, 2017).

Metoder er de måter, teknikker eller prosedyrer som forskeren bruker for å produsere og analysere empirisk materiale/data i forhold til det som er prosjektets forskningsspørsmål eller hensikt. Metoder for både produksjon og analyse/fortolkning kan blandes og krysses; grenser kan sprenges og ulike former for hybrider eller nyskapninger kan oppstå. Det er dette temanummeret et eksempel på.

I den første artikkelen i del 1 av temanummeret skriver dansekunstner og kunstfagdidaktiker Tone Pernille Østern artikkelen $\AA$ forske med kunsten som metodologisk praksis med aesthesis som mandat. I artikkelen bruker hun sin praktiske og teoretiske erfaring som veileder for master- og ph.d.-studenter til å skrive fram både stabiliseringspunkter og metodologiske propeller i det å forske med kunsten. Som resultat skriver hun fram det å forske med kunsten som en menings- og mulighetssøkende, produktiv og etisk metodologisk praksis, der særlig form, mening, nærhet, kropp, kontekst, etikk og diversitet fungerer som metodologiske propeller.

I temanummerets andre artikkel, $A$ skape et begrep om jam $i$ utforskningen av en deleuziansk metode-ontologi, diskuterer litteraturviter, jazzmusiker og lærerutdanner Ola Harstad hva metode er. Ved hjelp av Deleuze skriver han fram en metodeontologi, der han peker på metodologiens ontologiske dimensjon, og hvordan hele tilnærmingen til hvordan man forstår metodologi vitenskapsfilosofisk har stor betydning. Gjennom artikkelens gjennomgående dialog med Deleuze tilbyr han fra sitt ståsted 
det å jamme med teori som en fluktlinje fra (en tilstivnet) måte å tenke metode på, en fluktlinje som hele tiden holder metode i bliven.

Artiklene til Tone Pernille Østern og dramaturg Lise Hovik, musiker Njål Ølnes, musiker Tanja Orning og dansekunstner Rasmus Ölme er alle eksempler på artikler som handler om kunstnerisk forskning, skrevet av kunstner-forskere i en akademisk kontekst. Østern og Hovik undersøker i sin artikkel Med-koreografi og med-dramaturgi som diffraksjon sammen med en danser-koreograf og musiker-komponist hvordan koreografi og dramaturgi kan forvandles til med-koreografi og med-dramaturgi i en scenekunstnerisk prosess der bindeordet med aktivt forstås som metodologisk agent. I artikkelen leser de sin kunstneriske empiri med posthumanistisk vitenskapsfilosofisk teori. De peker på hvordan en forskyvning mot med virker inn produktivt på den koreografisk-dramaturgiske prosessen, både i den kunstneriske forskningsprosessen på gulvet og etterpå når de analyserer prosessen i artikkelen.

Ølnes undersøker i artikkelen $A$ forske på eiga speling fra innsiden av det improviserte samspillet i band, hvordan han kan forske på sin egen kunstneriske praksis uten at musikkens klingende aspekter går tapt. Som resultat, og ved hjelp av flere lyd- og videoeksempler, viser han hvordan auditiv sonologi fungerer som analyseredskap for å kunne utforske improvisasjonsprosessen innenfra den musikalske praksisen.

Orning undersøker i sitt arbeid som utøvende cellist med artikkelen Music as performance-gesture, sound and energy musikk som performance. Hun spør seg gjennom to eksempler fra egen kunstnerisk forskning hvordan hun som musiker-forsker kan forholde seg til og nettverke metodepluralismen i forskning som involverer kunstnerisk praksis. I artikkelen problematiserer hun forskningsmetodologiske utfordringer som oppstår i det musikk undersøkes ikke som et verk nedskrevet i et partitur, men som et levende objekt, som fremføring, lyd, klang, handling og kroppsliggjøring.

Ölme undersøker i sin artikkel Movement material hvordan et materialistisk perspektiv i praktisk og kunstnerisk utvikling av nåtidsdans og koreografi får teoretisk representasjon gjennom å lese prosjektet med (hovedsakelig) Jane Bennett og Gilles Deleuze. Kroppens kognitive og sanselige evner forstår han i artikkelen som relasjonelle i forhold til hverandre. Gjennom flere eksempler der han leser dansekunstnerisk praksis sammen med materialistisk teori skriver han fram aspekter ved materialitet ('matter') av betydning for dans og koreografi i samtiden.

Grafisk designer og lærerutdanner Mari Ann Letnes' artikkel Visualisering som drivkraft $i$ kunnskapsproduksjon et eksempel på hvordan forfatteren-forskeren inntar posisjonen som kunstpedagog og a/r/tograf (den hybride posisjonen som artist-researcher-teacher). Gjennom tre eksempler fra egen virksomhet som respektive artist, researcher och teacher viser hun hvordan det å visualisere som del av egen tankeprosess bidrar til selve tenkningen og kunnskapsproduksjonen. Visualiseringen fungerer som en drivkraft for forskningen.

Scene/dansekunstner Erikk McKenzies fagartikkel er den siste artikkelen i del 1 av temanummeret. I den artikulerer han en kunstnerisk utforskende prosess på det frie scenekunstfeltet. I Klima, karbon og koreografi skriver han om sin 
3-årige utforskende prosess av det norske oljeeventyret; en prosess som tok ham fra det makropolitiske til det personlige. Artikkelen får fram hvordan det å være scenekunstner/koreograf i dag ofte innebærer utforskende, personlige, samfunnsengasjerte prosesser der man aktivt tar del i det offentlige ordskiftet gjennom både dans og andre uttrykksformer.

Kunstnerisk og kunstpedagogisk forskning innebærer både frihet og ansvar. Kunstner/kunstpedagog-forskeren har ikke bare kunstnerens frihet, men også forskerens ansvar for å kontekstualisere seg selv og kritisk undersøke hvordan «the conditions are themselves conditioned» (Hannula, Suoranta \&Vadén, 2014, s. 4) eller med andre ord hvordan man selv er del av en allerede eksisterende kunstnerisk/kunstpedagogisk kontekst og kritisk forholder seg til den. Dette temanummeret bidrar til en slik kontekstualisering, motvirker privatisering av metoder for det å forske med kunsten og er fagfellesskapende - slik forskning skal være. Det å forske med kunsten utvikler og bør utvikle områder for anvendte og teorigenererende metodologier, samtidig som det utvikler en artikulering, et fagfellesskap, en ekspertise og et profesjonsfelt. Med dette temanummeret ønsker redaktører og forfattere å utfordre og stimulere forskere, kunstnere, kunstpedagoger, universiteter, høyskoler og andre samfunnsinstitusjoner til å ta ansvar for utviklingen og framtiden for det å forske med kunsten - et felt som har kommet for å bli, for å bidra, og for å endre forståelser av forskning og kunnskapsproduksjon. Vi tror og håper at temanummeret kan være til glede, provokasjon og inspirasjon for doktorgradsstipendiater, masterstudenter, kunstnere, kunstpedagoger, forskere og forskningsledere, både ved universiteter og høyskoler, og på det frie kunstfeltet i Norden, og utenfor.

Trondheim 18.12.2017

Redaktører for temanummeret $A$ forske med kunsten

Tone Pernille Østern

Mari Ann Letnes

\section{Referanser}

Academy of Finland (2009). Research in Art and Design in Finnish Universities. Evaluation Report. Publications of the Academy of Finland 4/09. Hentet fra http:/www.aka.fi/globalassets/awanhat/documents/ tiedostot/julkaisut/04_09-research-in-art-and-design.pdf (tilgang 09.11.2017)

Barad, K. (2007). Meeting the Universe Halfway. Quantum Physics and the Entanglement of Matter and Meaning. Durham and London: Duke University Press.

Colebrook, C. (2010). Gilles Deleuze. En introduktion. Göteborg: Bokförlaget Korpen.

Deleuze, G. \& Guattari, F. (1987/2013). A Thousand Plateaus. (Oversatt av B. Massumi). New York: Bloomsbury Publishing Plc.

Denzin, N.K. \& Lincoln, Y.S. (2005). The Sage Handbook of Qualitative Research. Thousand Oaks, California: SAGE.

Hannula, M., Suoranta, J. \& Vadén, T. (2014). Artistic Research Methodology. Narrative, Power and the Public. New York: Peter Lang.

Kara, H. (2015). Creative Research Methods in the Social Sciences. A Practical guide. Bristol and Chicago: Policy Press. 


\section{T.P. Østern og M.A. Letnes.}

Kaihovirta-Rosvik, H. (2009) Images of imagination: An aesthetic approach to education (Diss.).Vasa: Åbo Akademi University Press.

Lenz Taguchi, H. (2012). Pedagogisk dokumentation som aktiv agent. Introduktion till intra-aktiv pedagogik. Malmö: Gleerups.

Sharma, M. (2012). Indian art education and teacher identity as Deleuzo-Guattarian Assemblage: Narratives in a postcolonial globalization context (Diss). Hentet fra http://etd.ohiolink.edu/view.cgi?acc_num=osu1339617524 (tilgang 20.05.2015)

Torres de Eca, T. (2015). Artistic Ways of Inquiry in Arts Education Research. In S. Schonmann (Ed.), InternationalYearbook of Research in Arts Education (s. 467-471). Münster, New York: Waxmann.

Østern, T.P. (2017). Å forske med kunsten som metodologisk praksis med aesthesis som mandat. Fournal for Research in Arts and Sports Education. Special Issue: «Å forske med kunsten», Vol. 1, 2017, 7-27. 